\title{
SMALL RELIEF SHAPE VARIATIONS INFLUENCE SPATIAL VARIABILITY OF SOIL CHEMICAL ATTRIBUTES
}

\author{
Zigomar Menezes de Souza ${ }^{1}$; José Marques Júnior ${ }^{2 *}$; Gener Tadeu Pereira3; Diogo Mazza \\ Barbieri $^{1}$ \\ ${ }^{1}$ UNESP/FCAV - Programa de Pós-Graduação em Produção Vegetal. \\ ${ }^{2}$ UNESP/FCAV - Depto. de Solos e Adubos, Rod. Prof. Paulo Donato Castellane, s/n - 14884-900 - Jaboticabal, \\ $S P$ - Brasil. \\ ${ }^{3}$ UNESP/ FCAV - Depto de Ciências Exatas. \\ *Corresponding author < marques@fcav.unesp.br>
}

\begin{abstract}
Soils with small variations in relief and under the same management system present differentiated spatial variabilities of their attributes. This variability is a function of soil position in the landscape, even if the relief has little expression. The aim of this work was to investigate the effects of relief shape and depth on spatial variability of soil chemical attributes in a Typic Hapludox cultivated with sugar cane at two landscape compartments. Soil samples were collected in the intercrossing points of a grid, in the traffic line, at 0-0.2 $\mathrm{m}$ and $0.6-0.8 \mathrm{~m}$ depths, comprising a set of 100 georeferenced points. The spatial variabilities of $\mathrm{pH}, \mathrm{P}, \mathrm{K}, \mathrm{Ca}, \mathrm{Mg}$, cation exchange capacity and base saturation were quantified. Small relief shape variations lead to differentiated variability in soil chemical attributes as indicated by the dependence on pedoform found for chemical attributes at both $0-0.2 \mathrm{~m}$ and $0.6-0.8 \mathrm{~m}$ depths. Because of the higher variability, it is advisable to collect large number of samples in areas with concave and convex shapes. Combining relief shapes and geostatistics allows the determination of areas with different spatial variability for soil chemical attributes.
\end{abstract}

Key words: geostatistics, kriging, relief, sugar cane

\section{PEQUENAS VARIAÇÕES DAS FORMAS DE RELEVO INFLUENCIAM A VARIABILIDADE ESPACIAL DE ATRIBUTOS QUÍMICOS DO SOLO}

\begin{abstract}
RESUMO: Solos submetidos ao mesmo sistema de manejo em locais com pequena variação de relevo, manifestam variabilidade espacial diferenciada de seus atributos. Esta variabilidade é condicionada pela posição dos solos na paisagem ou no declive, mesmo que o relevo seja de pequena expressão. O estudo teve como objetivo avaliar a influência da forma do relevo na variabilidade espacial de atributos químicos em um latossolo cultivado com cana-de-açúcar em dois compartimentos da paisagem. Os solos foram amostrados nos pontos de cruzamento de uma malha, com intervalos regulares de $10 \mathrm{~m}$, perfazendo um total de 100 pontos, nas profundidades de $0-0,2 \mathrm{~m}$ e $0,6-0,8 \mathrm{~m}$. Foi avaliado a variabilidade espacial do $\mathrm{pH}$, fósforo $(\mathrm{P})$, potássio $(\mathrm{K})$, cálcio $(\mathrm{Ca})$, magnésio $(\mathrm{Mg})$, acidez potencial $(\mathrm{H}+\mathrm{Al})$, capacidade de troca catiônica (CTC) e saturação por bases (V\%). Pequenas variações nas formas do relevo condicionaram variabilidade diferenciada para os atributos químicos do solo. Os atributos químicos estudados apresentaram-se dependentes da pedoforma em ambas profundidades estudadas. Um maior número de amostras devem ser coletados em áreas com forma de relevo côncavo e convexo devido à maior variabilidade. $\mathrm{O}$ uso conjunto das formas do relevo e geoestatística possibilita definir áreas com diferentes variabilidades espaciais para atributos químicos do solo.

Palavras-chave: geoestatística, krigagem, relevo, cana-de-açúcar
\end{abstract}

\section{INTRODUCTION}

Scientific experimentation assumes the existence of random variability for soil attributes. Nevertheless, several studies have demonstrated that soil physical and chemical attributes are correlated with soil spatial distribution (Yost et al., 1982; Vieira et al., 1983; Tsegaye \& Hill, 1998; Carvalho et al., 2003). The distribution of these attributes may be influenced by successive soil management which leads to variability, even in soils considered highly homogenous, e.g. Oxisols 
that cover alarge area of cultivated soils in Brazil (Buol, 1990).

Working with landscape position can contribute to studies of soil chemical attributes (Kravchenko \& Bollock, 2000; Marques Jr. \& Lepsch, 2000; Mohanty \& Mousli, 2000; Pachepsky et al., 2001). Landscape variability associated with topographic features affects spatial patterns of water movement on both soil surface and subsurface, thus being able to affect nutrient availability (Li et al., 2001). It is supposed that relief (Halbfass \& Grunewald, 2003) and microrelief (Kuzyakova et al., 1997) are also factors that greatly affect soil spatial variability. Concave and convex relief shapes show different variability as compared with linear micro-relieves, mainly because of the water flow. The aim of this work was to investigate the effects of small variations in relief shape and depth on the spatial variability of soil chemical attributes in a Typic Hapludox cultivated with sugar cane at two landscape compartments.

\section{MATERIAL AND METHODS}

The studied site was located in Guariba, SP, Brazil ( $21^{\circ} 19^{\prime} \mathrm{S}, 48^{\circ} 13^{\prime} \mathrm{W}$; altitude $\left.640 \mathrm{~m}\right)$. The area's climate is Cwa according to Köppen's classification. The mean annual rainfall is $1.400 \mathrm{~mm}$; precipitation is concentrated from November to February.

The area's relief is soft wavy and the slope varies from 3 to $8 \%$. The site has been cropped with sugar cane for 30 years and it was the 5th harvest at the moment of soil sampling. The Typic Hapludox, a clay-textured soil (LVef), was originated from Basalts of São Bento Group, "Serra Geral" formation.

According to the Troeh's model (Troeh, 1965), the curvature and profile of the landscape in the lower $1 / 3$ of the hillslope were classified into two compartments (I and II; Figure 1). In the compartment I the relief was basically linear-shaped, while in compart-

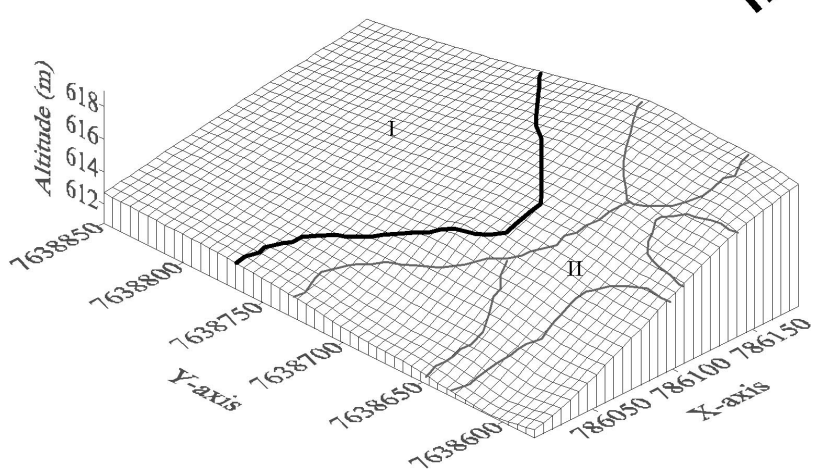

Figure 1 - Study area map. Compartments I (linear) and II (concave-convex) are identified. ment II it was concave- and convex-shaped. Soil samples were collected in the intercrossing points of a grid $(10 \times 10 \mathrm{~m}$; area $=1 \mathrm{ha})$, in the traffic line and at $0-0.2 \mathrm{~m}$ and $0.6-0.8 \mathrm{~m}$ depths. One hundred points were georeferenced in the grid.

The active acidity $\left(\mathrm{pH}\right.$ in $\left.\mathrm{CaCl}_{2} 0.01 \mathrm{moL} \mathrm{L}^{-1}\right)$ was determined by a potentiometer using a $1: 2.5$ soil: $\mathrm{CaCl}_{2}$ ratio, and the potential acidity $(\mathrm{H}+\mathrm{Al})$ was determined according to Raij et al. (2001). The ion exchange resin method (Raij et al., 2001) was used for $\mathrm{Ca}, \mathrm{Mg}$ and $\mathrm{K}$ and available $\mathrm{P}$ extractions. Based on chemical analyses, cation exchange capacity (CEC) and base saturation (\%BS) were calculated.

Sampling size was calculated by the Equation (1) described by Warrick \& Nielsen (1980):

$$
\mathrm{N}=\left(\mathrm{T}_{\alpha} \times \sigma\right)^{2} / \mathrm{D}^{2},
$$

where $\mathrm{N}$ is the minimal number of samples; $\mathrm{T}_{\alpha}$ is the value of Student's T test at $95 \%$ probability level; $\sigma$ is the coefficient of variation; and $\mathrm{D}$ is the percentage of variation respective to the mean $(5,10$ or $15 \%)$. Soil variability was firstly assessed by exploratory analyses (mean, median, coefficient of variation, asymmetry and kurtosis). Normality was tested by Kolmogorov-Smirnov's test (SAS, 1995).

Using the regionalized variable theory, the spatial variation was calculated by the semiovariogram method (Journel \& Huijbregts, 1991) that assumes the stationarity of the intrinsic hypothesis and is expressed by the following equation:

$$
\gamma(h)=\frac{1}{2} E\left[Z\left(x_{i}\right)-Z\left(x_{i}+h\right)\right]^{2},
$$

which is a function of the vector $\mathrm{h}$, and thus depends on the magnitude and direction of $h$.

The semivariance was estimated by the following equation:

$$
\hat{\gamma}(h)=\frac{1}{2 N(h)} \sum_{i=1}^{N(h)}\left[Z\left(x_{i}\right)-Z\left(x_{i}+h\right)\right]^{2},
$$

where $\mathrm{N}(\mathrm{h})$ is the number of measured point pairs $\mathrm{Z}\left(\mathrm{x}_{\mathrm{i}}\right), \mathrm{Z}\left(\mathrm{x}_{\mathrm{i}}+\mathrm{h}\right)$, separated by a vector $\mathrm{h}$. The graphic plotted from $\hat{\gamma}(h)$ and the corresponding $\mathrm{h}$ values are named semiovariogram.

The theoretical model coefficients of the semiovariogram were determined by the fitness of the mathematical model to the $\hat{\gamma}(h)$ values. The following models were fitted to the data: (a) spherical (Sph), $\hat{\gamma}(h)=\mathrm{C}_{0}+\mathrm{C}_{1}\left[1.5(\mathrm{~h} / \mathrm{a})-0.5(\mathrm{~h} / \mathrm{a})^{3}\right]$, for $0<\mathrm{h}<\mathrm{a}$, and $\hat{\gamma}(h)=\mathrm{C}_{0}+\mathrm{C}_{1}$ for $\mathrm{h}>\mathrm{a}$; and (b) exponential (Exp), $\hat{\gamma}(h)=\mathrm{C}_{0}+\mathrm{C}_{1}[1-\exp (-3 \mathrm{~h} / \mathrm{a})]$, for $0<\mathrm{h}<\mathrm{d}$, where $\mathrm{C}_{0}$ is the nugget effect, $\mathrm{C}_{0}+\mathrm{C}_{1}$ is the sill, a is the range and $\mathrm{d}$ is the maximal distance in which the semiovariogram is defined. 
To determine the spatial dependence, the semivariogram examination was performed with the program GS ${ }^{+}$(Gamma Design Inc., Plainwell, MI). When more than one variogram could be used, the most appropriated was chosen by the cross-validation method. The software Surfer 7.0 (Golden Software, Inc., New York, NY, 1999) was used for plotting the spatial distribution maps of the variables. The spatial dependence of the investigated variables was performed according to the classification of Cambardella et al. (1994).

\section{RESULTS AND DISCUSSION}

The minimal number of samples required with 5,10 and $15 \%$ of variation respective to the mean was assessed for each compartment by the Warrick \& Nielsen's formula (Table 1) (Warrick \& Nielsen, 1980). The required number of samples was relatively high for $\mathrm{P}, \mathrm{K}, \mathrm{Ca}, \mathrm{Mg}, \mathrm{H}+\mathrm{Al}, \mathrm{CEC}$ and $\mathrm{BS} \%$, as also described by Silveira et al. (2000). On the other hand, a small number of sub-samples was necessary for estimating $\mathrm{pH}$, in agreement with Tsegaye \& Hill (1998) and Silveira et al. (2000). Generally, a higher number of samples was required in the compartment II where all studied variables presented higher variability. Similar results were found by Montanari et al. (2005) for

Table 1 - Estimative of the minimal number of samples required with 5,10 and $15 \%$ variation respective to the mean in each landscape compartment.

\begin{tabular}{|c|c|c|c|c|c|}
\hline Variable & Compartment & C.V. & 5 & 10 & 15 \\
\hline & & & \multicolumn{3}{|c|}{$-\cdots$} \\
\hline \multirow[t]{2}{*}{$\mathrm{P}\left(\mathrm{mg} \mathrm{dm}^{-3}\right)$} & I & 33 & 176 & 44 & 20 \\
\hline & II & 53 & 453 & 113 & 50 \\
\hline \multirow[t]{2}{*}{$\mathrm{K}\left(\mathrm{mmol}_{\mathrm{c}} \mathrm{dm}^{-3}\right)$} & I & 37 & 221 & 55 & 25 \\
\hline & II & 58 & 543 & 136 & 60 \\
\hline \multirow[t]{2}{*}{$\mathrm{Ca}\left(\mathrm{mmol}_{\mathrm{c}} \mathrm{dm}^{-3}\right)$} & I & 25 & 101 & 25 & 11 \\
\hline & II & 39 & 246 & 61 & 27 \\
\hline \multirow[t]{2}{*}{$\mathrm{Mg}\left(\mathrm{mmol}_{\mathrm{c}} \mathrm{dm}^{-3}\right)$} & I & 32 & 165 & 41 & 18 \\
\hline & II & 46 & 342 & 85 & 38 \\
\hline \multirow[t]{2}{*}{$\mathrm{pH}\left(\mathrm{CaCl}_{2}\right)$} & I & 5.3 & 5 & 1 & 1 \\
\hline & II & 6.8 & 7 & 2 & 1 \\
\hline \multirow[t]{2}{*}{${ }^{1} \mathrm{H}+\mathrm{Al}\left(\mathrm{mmol}_{\mathrm{c}} \mathrm{dm}^{-3}\right)$} & I & 21 & 71 & 18 & 8 \\
\hline & II & 28 & 127 & 32 & 14 \\
\hline \multirow[t]{2}{*}{${ }^{2} \mathrm{CEC}\left(\mathrm{mmol}_{\mathrm{c}} \mathrm{dm}^{-3}\right)$} & I & 11 & 20 & 5 & 2 \\
\hline & II & 17 & 47 & 12 & 5 \\
\hline \multirow[t]{2}{*}{$30 \mathrm{BS}$} & I & 21 & 71 & 18 & 8 \\
\hline & II & 29 & 136 & 34 & 15 \\
\hline
\end{tabular}

${ }^{1} \mathrm{H}+\mathrm{Al}=$ potential acidity; ${ }^{2} \mathrm{CEC}=$ cation exchange capacity; and $3 \% \mathrm{BS}=$ base saturation. the spatial variability of chemical attributes in soil cropped with sugar cane in different pedoforms. This shows that small variations in relief must be considered for sampling delineations in experiments with the same scale.

Data distribution was normal for the CEC and $\% \mathrm{BS}$, in both depths, and for the $\mathrm{K}$, in the $0.0-0.2 \mathrm{~m}$ depth, according to the Kolmogorov-Smirnov's test ( $\alpha$ $=0.05)$ (Table 2). Dobermann \& George (1994) found normal distribution of $\mathrm{pH}$, and Souza et al. (2003) to $\mathrm{P}, \mathrm{K}$ and $\% \mathrm{BS}$ in a study of the effect of relief on anisotropic variation of chemical attributes at $0-0.2 \mathrm{~m}$ depth. Despite showing some asymmetric distributions, mean and median values were similar for all the investigated variables which indicate that the measures of central tendency are not dominated by atypical values (Cambardella et al., 1994). However, any theoretical distribution is always matched inexactly because data from nature are under the effect of several concomitant factors (Cressie, 1991).

The variabilities of the soil chemical attributes are shown in Table 2 and were analyzed by criteria of Warrick \& Nielsen (1980). Soil pH variability was considered low $(<12 \%)$. Similar variabilities were reported to poorly drained soil cropped with rye (Tsegaye \& Hill, 1998), Alfisol (Chung et al., 1995) and Entisol cropped with corn at 0-0.2 depth (Castrignanò et al., 2000), and Oxisol cropped with sugar cane at 0.6-0.8 depth (Souza et al., 2003).

For $\mathrm{H}+\mathrm{Al}, \mathrm{CEC}$ and $\% \mathrm{BS}$, the $\mathrm{CVs}$ were between 12 and $24 \%$, higher than the CV observed for $\mathrm{pH}$. Variabilities of $\mathrm{H}+\mathrm{Al}$ were similar to those found in an Oxisol at the same depths here in considered (Souza et al., 2003), and in a Podzolic with native vegetation (Park \& Vlek, 2002). CVs within this range were also reported in an Oxisol cropped with corn during the summer and winter, considering only the $0-0.2$ $m$ depth (Silveira et al., 2000). Considering the \%BS, this range of variability was similar to those reported to an Ultisol under native vegetation at $0-0.2 \mathrm{~m}$ depth (Park \& Vlek, 2002) and a sugar cane-cropped Oxisol at 0-0.2 $\mathrm{m}$ and 0.6-0.8 $\mathrm{m}$ depths (Souza et al., 2003).

Registered CVs for CEC are similar to those described for a corn and soybean cropped Molisol (Cambardella et al., 1994), to a 30-year sugar canecropped Oxisol (Souza et al., 2003) and to a corn cropped Entisol sampled at the same soil depths investigated here (Castrignanò et al., 2000). P, K, Ca and Mg showed higher variabilities, above $24 \%$ at the two studied depths. At these same depth conditions, Souza et al. (2003) found variabilities higher than $24 \%$. This is similar to data reported to a corn and soybean cropped Molisol (Cambardella et al., 1994) and to a grape cropped Alfisol sampled at the lower 0-0.2 m 
Table 2 - Descriptive (mean, median, coefficient of variation (CV), asymmetry and kurtosis) and normality analyses of soil attributes.

\begin{tabular}{|c|c|c|c|c|c|c|}
\hline \multirow{2}{*}{ Soil Properties } & \multicolumn{5}{|c|}{ Descriptive analyses } & \multirow{2}{*}{$\mathrm{d}^{1}$} \\
\hline & mean & Median & $\mathrm{CV}$ & asymmetry & kurtosis & \\
\hline \multicolumn{7}{|c|}{ - 0.2 m - } \\
\hline $\mathrm{P}\left(\mathrm{mg} \mathrm{dm} \mathrm{m}^{-3}\right)$ & 22.53 & 22.11 & 40.43 & 0.15 & 0.37 & 0.11 \\
\hline $\mathrm{K}\left(\mathrm{mmol}_{\mathrm{c}} \mathrm{dm}^{-3}\right)$ & 3.07 & 3.01 & 33.91 & 0.32 & -0.43 & $0.06^{\mathrm{ns}}$ \\
\hline $\mathrm{Ca}\left(\mathrm{mmol}_{\mathrm{c}} \mathrm{dm}^{-3}\right)$ & 25.90 & 25.61 & 33.46 & 0.21 & -0.52 & 0.08 \\
\hline $\operatorname{Mg}\left(\mathrm{mmol}_{\mathrm{c}} \mathrm{dm}^{-3}\right)$ & 9.83 & 10.01 & 30.76 & 0.15 & -0.33 & 0.09 \\
\hline $\mathrm{pH}\left(\mathrm{CaCl}_{2}\right)$ & 4.81 & 4.80 & 5.37 & 0.05 & -0.08 & 0.10 \\
\hline $\mathrm{H}+\mathrm{Al}\left(\mathrm{mmol}_{\mathrm{c}} \mathrm{dm}^{-3}\right)$ & 45.84 & 47.01 & 22.69 & 0.14 & -0.55 & 0.10 \\
\hline $\mathrm{CEC}\left(\mathrm{mmol}_{\mathrm{c}} \mathrm{dm}^{-3}\right)$ & 85.73 & 85.90 & 17.81 & -0.06 & -0.09 & $0.04^{\mathrm{ns}}$ \\
\hline$\% \mathrm{BS}$ & 45.42 & 44.51 & 21.87 & 0.03 & -0.96 & $0.08^{\mathrm{ns}}$ \\
\hline \multicolumn{7}{|c|}{ 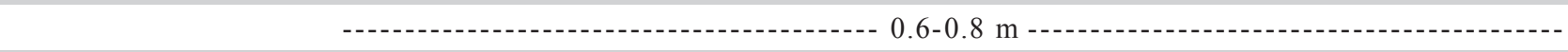 } \\
\hline $\mathrm{P}\left(\mathrm{mg} \mathrm{dm} \mathrm{m}^{-3}\right)$ & 5.61 & 5.11 & 31.62 & 0.81 & 1.02 & 0.17 \\
\hline $\mathrm{K}\left(\mathrm{mmol}_{\mathrm{c}} \mathrm{dm}^{-3}\right)$ & 0.77 & 0.70 & 33.58 & 0.59 & -0.09 & 0.13 \\
\hline $\mathrm{Ca}\left(\mathrm{mmol}_{\mathrm{c}} \mathrm{dm}^{-3}\right)$ & 17.90 & 17.01 & 27.61 & 0.34 & 0.16 & 0.11 \\
\hline $\operatorname{Mg}\left(\mathrm{mmol}_{\mathrm{c}} \mathrm{dm}^{-3}\right)$ & 7.08 & 7.01 & 26.63 & -0.12 & -0.35 & 0.13 \\
\hline $\mathrm{pH}\left(\mathrm{CaCl}_{2}\right)$ & 5.00 & 4.90 & 4.21 & -0.04 & -0.42 & 0.07 \\
\hline $\mathrm{H}+\mathrm{Al}\left(\mathrm{mmol}_{\mathrm{c}} \mathrm{dm}^{-3}\right)$ & 36.35 & 34.25 & 16.27 & 0.82 & 0.55 & 0.16 \\
\hline $\mathrm{CEC}\left(\mathrm{mmol}_{\mathrm{c}} \mathrm{dm}^{-3}\right)$ & 62.09 & 61.11 & 13.22 & 0.36 & 0.37 & $0.07^{\mathrm{ns}}$ \\
\hline$\% \mathrm{BS}$ & 42.43 & 43.12 & 20.46 & -0.38 & -0.28 & $0.06^{\mathrm{ns}}$ \\
\hline
\end{tabular}

${ }^{1} \mathrm{~d}$ values (Kolmogorov-Smirnov's normality test; ${ }^{\text {ns }}=$ normally distributed At $P<0.05$ )

depth (Carvalho et al., 2003). High CVs were reported for $\mathrm{Ca}$ and $\mathrm{Mg}$, and extremely high values were reported for $\mathrm{P}$ (Chien et al., 1997); Castrignanò et al. (2000) found high $\mathrm{Ca}$ and $\mathrm{Mg} \mathrm{CV}$ values for corncropped Typic Xerofluvent. Moderate CV is not necessarily a good indicator of spatial variability of soil attributes because of differences in soil nutrients caused by management procedures (Wollenhaupt et al., 1997).

The Oxisol concept implies that soil characteristics are homogeneous, both in profile and horizontal extension. Nevertheless, a 30-year sugar cane-cropped surface was not homogeneous even in the surface, as showed here by the high variability of soil attributes, especially $\mathrm{K}, \mathrm{P}, \mathrm{Ca}$ and $\mathrm{Mg}$. Several factors affect the extension of the spatial variability in a soil unity, as well as the degree of this variability extension affects the association between productivity and soil surveys (Sadler \& Russel, 1997).

Results for the geostatistics analysis are presented in Table 3. All the analyzed variables presented spatial dependence for both investigated depths. $\mathrm{K}, \mathrm{pH}$, $\mathrm{Ca}, \mathrm{H}+\mathrm{Al}, \mathrm{CEC}$ and $\% \mathrm{BS}$ fitted to a spherical model and $\mathrm{P}$ and $\mathrm{Mg}$ to an exponential model at $0-0.2 \mathrm{~m}$ depth. However, at 0.6-0.8 m depth, only $\mathrm{K}, \mathrm{Ca}, \mathrm{H}+\mathrm{Al}$ and CEC fitted better to a spherical model, while $\mathrm{pH}$, $\mathrm{P}, \mathrm{Mg}$ and $\% \mathrm{BS}$ fitted better to an exponential model.
In a study of the effect of intensive soil use on plant and soil nutrient spatial variability, it was found that all these variables fitted well to the spherical model (Tsegaye \& Hill, 1998). In another work soil attributes also fitted well to a spherical model (Cambardella et al., 1994).

The nugget effect (Table 3 ) represents the random variation usually derived from the inaccuracy of measurements or variations of the properties that cannot be detected in the sample range (Trangmar et al., 1985). The nugget effect in the semiovariograms found here were not high because of the short distance among consecutive sampling points. The parameters of the semiovariogram (sill and range) for the soil chemical attributes are similar between depths, without significant modifications in the spatial dependence (Table 3). The relation $\mathrm{C}_{0} /\left(\mathrm{C}_{0}+\mathrm{C}_{1}\right)$ indicates that the investigated variables showed a moderate spatial dependence, except for $\mathrm{Ca}$ that expressed a stronger spatial dependence at 0-0.2 m depth. At the 0.6-0.8 $\mathrm{m}$ depth, $\mathrm{pH}, \mathrm{P}$, $\mathrm{Mg}$ and $\% \mathrm{BS}$ showed moderate spatial dependence, while $\mathrm{K}, \mathrm{Ca}, \mathrm{H}+\mathrm{Al}$ and $\mathrm{CEC}$ were strongly dependent on the soil's spatial distribution. The higher $\mathrm{C}_{0} /\left(\mathrm{C}_{0}+\mathrm{C}_{1}\right)$ values indicate that the soil may present lower-scaled variability than those presented here, and that more intensive sampling may reveal a higher spatial continuum of the attributes analyzed. 
Table 3 - Parameters for variogram models for soil attributes.

\begin{tabular}{|c|c|c|c|c|c|c|}
\hline Soil Properties & Model & Nugget $\left(\mathrm{C}_{0}\right)$ & Sill $\left(\mathrm{C}_{0}+\mathrm{C}_{1}\right)$ & range (a) & Nugget/ Sill x 100 & ${ }^{1} \mathrm{r}^{2}$ \\
\hline \multicolumn{7}{|c|}{ - $0.2 \mathrm{~m}-\mathrm{m}_{-1}$} \\
\hline $\mathrm{P}\left(\mathrm{mg} \mathrm{dm}^{-3}\right)$ & Exponential & 9.26 & 32.45 & 27.90 & 28 & 88 \\
\hline $\mathrm{K}\left(\mathrm{mmol}_{\mathrm{c}} \mathrm{dm}^{-3}\right)$ & Spherical & 0.74 & 1.49 & 41.00 & 50 & 94 \\
\hline $\mathrm{Ca}\left(\mathrm{mmol}_{\mathrm{c}} \mathrm{dm}^{-3}\right)$ & Spherical & 9.90 & 47.60 & 28.70 & 21 & 93 \\
\hline $\mathrm{Mg}\left(\mathrm{mmol}_{\mathrm{c}} \mathrm{dm}^{-3}\right)$ & Exponential & 2.83 & 8.62 & 58.5 & 33 & 97 \\
\hline $\mathrm{pH}\left(\mathrm{CaCl}_{2}\right)$ & Spherical & 0.02 & 0.07 & 48.10 & 29 & 98 \\
\hline $\mathrm{H}+\mathrm{Al}\left(\mathrm{mmol}_{\mathrm{c}} \mathrm{dm}^{-3}\right)$ & Spherical & 20.80 & 75.80 & 51.30 & 28 & 98 \\
\hline $\operatorname{CEC}\left(\mathrm{mmol}_{\mathrm{c}} \mathrm{dm}^{-3}\right)$ & Spherical & 61.11 & 125.23 & 56.20 & 49 & 98 \\
\hline \multirow[t]{2}{*}{$\% \mathrm{BS}$} & Spherical & 39.30 & 93.41 & 47.50 & 42 & 99 \\
\hline & \multicolumn{6}{|c|}{$0.6-0.8 \mathrm{~m}-1.0$} \\
\hline $\mathrm{P}\left(\mathrm{mg} \mathrm{dm}^{-3}\right)$ & Exponential & 2.54 & 9.21 & 37.20 & 28 & 93 \\
\hline $\mathrm{K}\left(\mathrm{mmol}_{\mathrm{c}} \mathrm{dm}^{-3}\right)$ & Spherical & 0.01 & 0.07 & 24.70 & 14 & 91 \\
\hline $\mathrm{Ca}\left(\mathrm{mmol}_{\mathrm{c}} \mathrm{dm}^{-3}\right)$ & Spherical & 6.49 & 28.78 & 23.50 & 23 & 96 \\
\hline $\mathrm{Mg}\left(\mathrm{mmol}_{\mathrm{c}} \mathrm{dm}^{-3}\right)$ & Exponential & 0.70 & 2.39 & 28.20 & 29 & 95 \\
\hline $\mathrm{pH}\left(\mathrm{CaCl}_{2}\right)$ & Exponential & 0.03 & 0.10 & 59.70 & 30 & 94 \\
\hline $\mathrm{H}+\mathrm{Al}\left(\mathrm{mmol}_{\mathrm{c}} \mathrm{dm}^{-3}\right)$ & Spherical & 8.60 & 68.52 & 22.30 & 13 & 81 \\
\hline $\mathrm{CEC}\left(\mathrm{mmol}_{\mathrm{c}} \mathrm{dm}^{-3}\right)$ & Spherical & 6.40 & 73.07 & 26.30 & 9 & 95 \\
\hline$\% \mathrm{BS}$ & Exponential & 26.20 & 87.91 & 42.90 & 30 & 97 \\
\hline
\end{tabular}

${ }^{1} \mathrm{r}^{2}=$ coefficient of determination for model-semivariance fit.

The higher spatial dependence of chemical attributes occurred at $0.6-0.8 \mathrm{~m}$ depth and then was associated to the low level of management. The spatial variability of soil attributes may be affected by intrinsic and extrinsic factors, the latter resulting usually from soil management (Cambardella et al., 1994).

The variable range can be sequenced in increasing order for the $0-0.2 \mathrm{~m}$ depth, as follow (values in Table 3): $\mathrm{P}<\mathrm{Ca}<\mathrm{K}<\% \mathrm{BS}<\mathrm{pH}<\mathrm{H}+\mathrm{Al}<$ $\mathrm{CEC}<\mathrm{Mg}$. The following sequence was found for the 0.6-0.8 m depth: $\mathrm{H}+\mathrm{Al}<\mathrm{Ca}<\mathrm{K}<\mathrm{CEC}<\mathrm{Mg}<$ $\mathrm{P}<\% \mathrm{BS}<\mathrm{pH}$. These values were always lower at the 0.0-0.8 $\mathrm{m}$ depth, except for $\mathrm{pH}$ and $\mathrm{P}$, indicating a higher spatial distribution discontinuity for the soil chemical attributes at higher depth. Considering $\mathrm{P}$, the higher value at the surface layer $(0-0.2 \mathrm{~m})$ can be a function of fertilization in this layer, because this nutrient has a low mobility in the soil (Raij et al., 2001). For the $\mathrm{pH}$, the sequence is probably also determined by effects of nitrogenous fertilization. These results are similar to those reported by Souza et al. (2003) for P. Soil management with fertilizers and turning over the ground may contribute to the increase in the range and decrease spatial dependence, characterizing a higher continuum in the distribution of the elements at the surface sampled layer.
The chemical attributes and Kriging's maps vary from low to very high fertility (Table 2, Figures 2 and 3). These values show large amplitudes which imply that in some places of the area the fertilizer application may be excessive. The higher values detected in the deeper layer (0.6-0.8) in comparison to the surface, may be even due to this high amplitude. Inadequate soil chemical management hampers fertilization efficiency and cause leaching of excessive fertilizers (Bhatti et al., 1991), therefore resulting in economical losses from both nutrient unbalance and environmental impact.

In the higher region with homogeneous profile and relief shape (compartment I), the variability was lower (Figures 1, 2, and 3) for all the studied variables. On the other hand, in the lower region, in the most heterogeneous area (compartment II), the variability was higher. This relation with the landscape position has also been reported by other studies. Geostatistics may help evaluation of spatial dependence of chemical attributes in the landscape, with the nutrient availability at least partially controlled by the position of the landscape (Amador et al., 1997 and Vaidya \& Pal, 2002). Furthermore, Brubaker et al. (1993) and Vaidya \& Pal (2002) reported that soil chemical attributes and position in the landscape are interrelated, as also reported in the present study. 

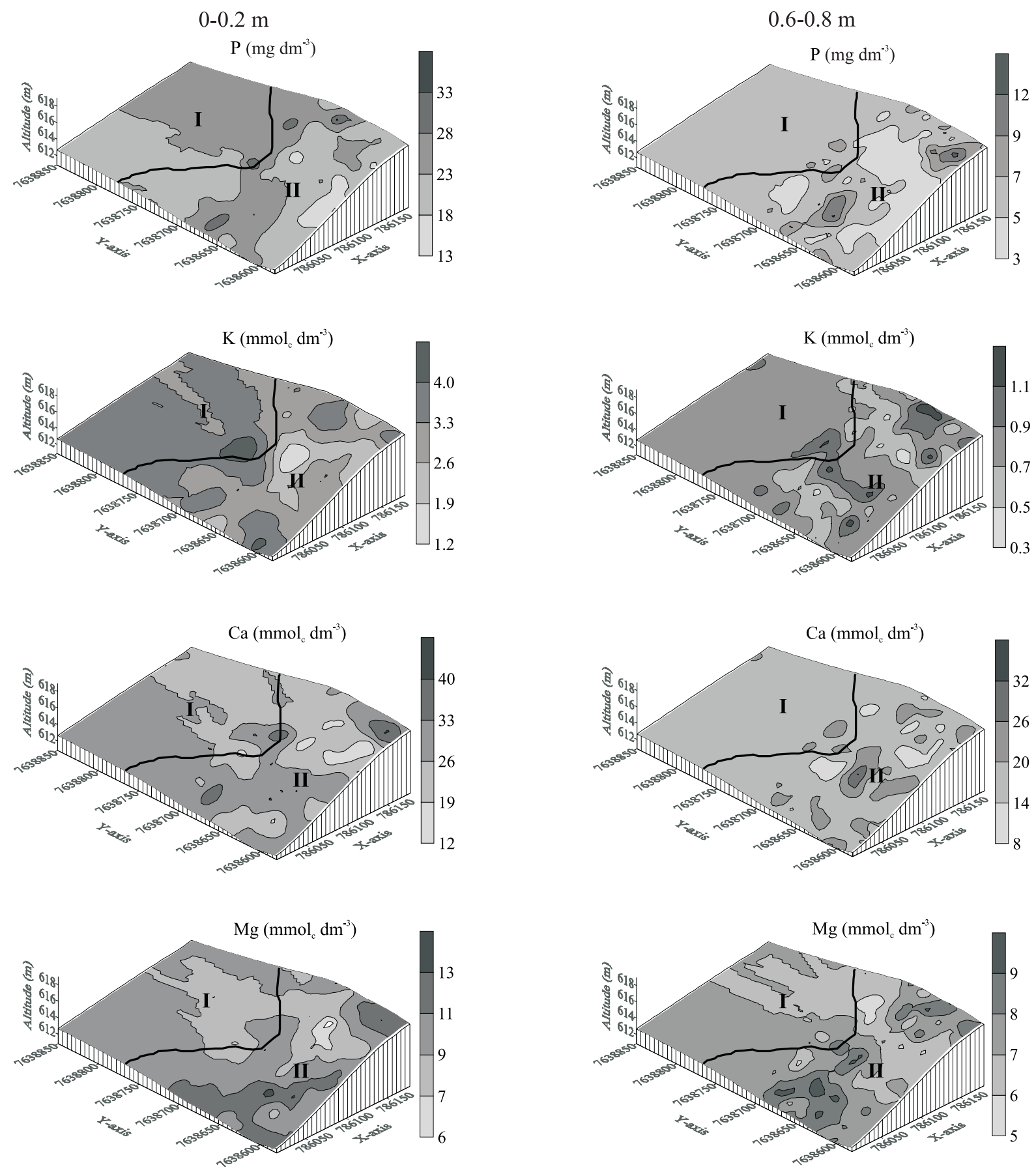

Figure 2 - Contour maps of soil attributes at 0-0.2 $\mathrm{m}$ and 0.6-0.8 depth. $\mathrm{P}=$ phosphorus, $\mathrm{K}=$ potassium, $\mathrm{Ca}=\mathrm{calcium}$ and $\mathrm{Mg}=$ magnesium.

Differences in spatial variability of soil chemical attributes in different pedoforms are probably associated to small variations in relief shape, which was the principal factor determining the highest variability found in the concave and convex pedoforms. Similar results were found by Souza et al. (2003; 2004). These results support the idea that lateral and superficial fluxes of water in concave and convex forms determine specific environments that interfere in pedogenetic processes and favor the development of a higher spatial variability for soil attributes (Franzen et al., 1998).

\section{ACKNOWLEDGEMENTS}

To Fundação de Amparo à Pesquisa do Estado de São Paulo (FAPESP) for the scholarship granted to the first author (00/10210-2). 

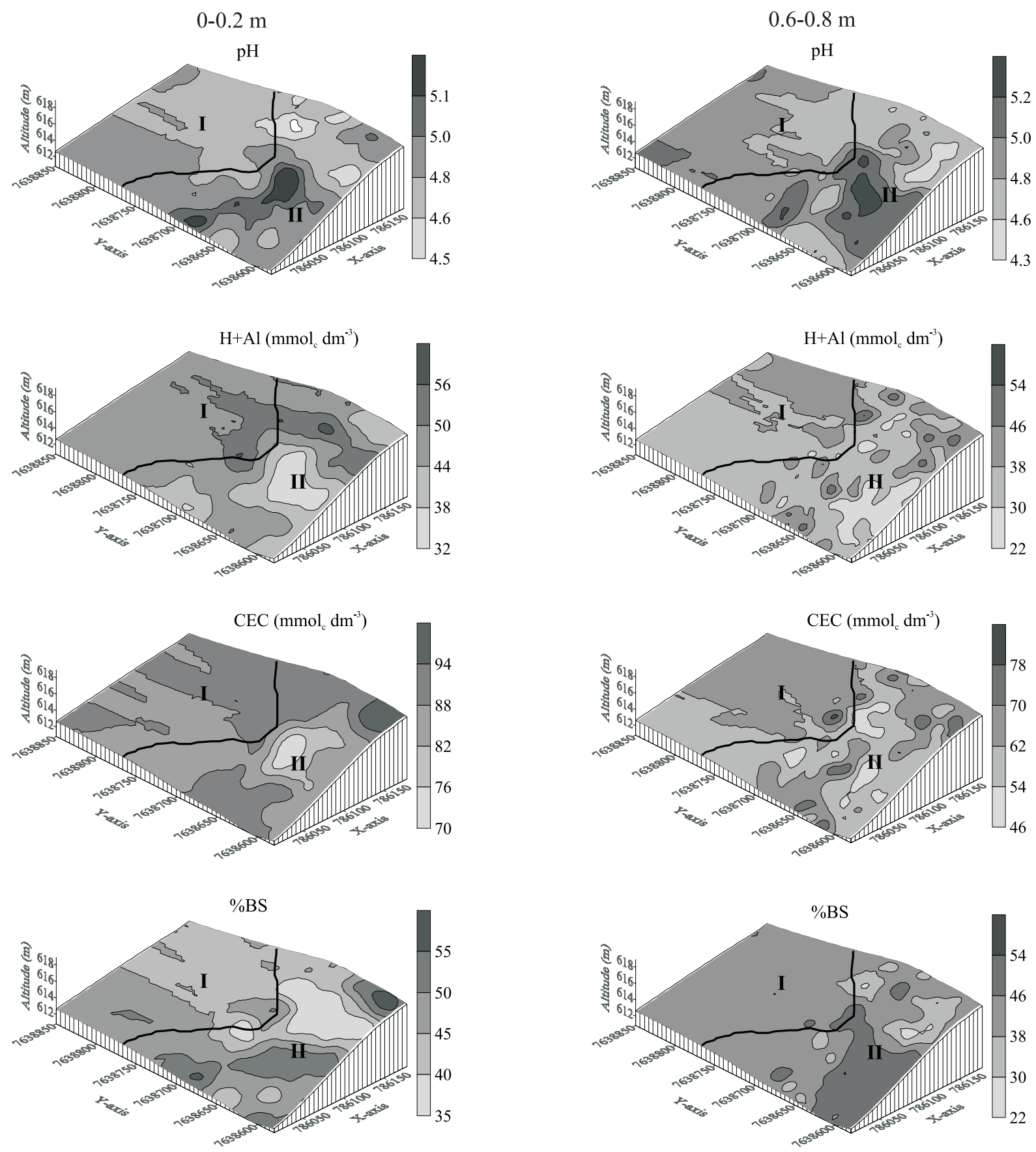

Figure 3 - Contour maps of soil attributes at 0-0.2 $\mathrm{m}$ and 0.6-0.8 depth. $\mathrm{pH}, \mathrm{H}+\mathrm{Al}=$ potential acidity, $\mathrm{CEC}=$ cation exchange capacity and $\% \mathrm{BS}=$ base saturation.

\section{REFERENCES}

AMADOR, J.A.; GLUCKSMAN, A.M.; LYONS, J.B.; CORRES, J.H. Spatial distribution of soil phosphatase activity within a riparian forest. Soil Science, v.162, p.808-825, 1997.

BHATTI, A.U.; MULLA, D.J.; FRAZIER, B.E. Estimation of soil properties and wheat yields on complex eroded hills using geostatistics and thematic mapper images. Remote Sensing of Environment, v.37, p.181-191, 1991.

BRUBAKER, S.C.; JONES, A.J.; LEWIS, D.T.; FRANK, K. Soil properties associated with landscape position. Soil Science Society of America Journal, v.57, p.235-239, 1993.
BUOL, S.W. Suelos tropicales: clasificación y características. In: SALINAS, J.G.; GOULEY, L.M. Sorgo para suelos ácidos. Cali: CIAT, 1990. p.49-62.

CAMBARDELLA, C.A.; MOORMAN, T.B.; NOVAK, J.M.; PARKIN, T.B.; KARLEN, D.L.; TURCO, R.F.; KONOPKA, A.E. Field-scale variability of soil properties in Central Iowa Soils. Soil Science Society of America Journal, v.58, p.1501-1511, 1994.

CARVALHO, M.P.; TAKEDA, E.Y.; FREDDI, O.S. Variabilidade espacial de atributos de um solo sob videira em Vitória Brasil (SP). Revista Brasileira de Ciência do Solo, v.27, p.695-703, 2003. 
CASTRIGNANÒ, A.; GIUGLIARINI, L.; RISALITI, R; MARTINELLI, N. Study of spatial relationships among some soil physico-chemical properties of a field in central Italy using multivariate geostatistics. Geoderma, v.97, p.39-60, 2000.

CHIEN, Y.J.; LEE, D.Y.; GUO, H.Y.; HOUNG, K.H. Geostatistical analysis of soil properties of mid-west Taiwan soils. Soil Science, v.162, p.291-298, 1997.

CHUNG, C.K.; CHONG, S.K; VARSA, E.C. Sampling strategies for fertility on a stoy silt loam soil. Communications in Soil Science and Plant Analysis, v.26, p.741-763, 1995.

CRESSIE, N. Statistics for spatial data. New York: John Wiley, 1991. 900p.

DOBERMANN, A.; GEORGE, T. Field-scale soil fertility variability in acid tropical soils. In: WORLD CONGRESS OF SOIL SCIENCE, 15., Acapulco, 1994. Proceedings. Acapulco, 1994. v.5, p.610-627.

FRANZEN, D.W.; CIHACEK, L.J.; HOFMAN, V.L.; SWENSON, L.J. Topography-based sampling compared with grid sampling in the northern great plains. Journal of Production Agriculture, v.11, p.364-370, 1998.

HALBFASS, S.; GRUNEWALD, K. Spatial variability of phosphorus contents in topsoils of two small catchments under agricultural use. Journal of Plant Nutrition and Soil Science, v.166, p.197-203, 2003.

JOURNEL, A.G.; HUIJBREGTS, C.J. Mining geostatistics. London: Academic Press, 1991. 600p.

KRAVCHENKO, A.N.; BOLLOCK, D.G. Correlation of corn and soybean yield with topography and soil properties. Agronomy Journal, v.75, p.75-83, 2000.

KUZYAKOVA, I.F.; KUZYAKOV, Y.V.; THOMAS, E. Effect of microrelief on the spatial variability of carbon content of a Podzoluvisol in a long term field trial. Journal of Plant Nutrition and Soil Science, v.160, p.555-561, 1997.

LI, H.; LASCANO, R.J.; BOOKER, J.; WILSON, L.T.; BRONSON, K.F. Cotton lint yield variability in a heterogeneous soil at a landscape scale. Soil \& Tillage Research, v.58, p.245-258, 2001.

MARQUES JR., J.; LEPSCH, I.F. Depósitos superficiais neocenozóicos, superfícies geomórficas e solos em Monte Alto, SP. Geociências, v.19, p.265-281, 2000.

MOHANTY, B.P.; MOUSLI, Z. Saturated hydraulic conductivity and soil water retention properties across a soil-slope transition. Water Resources Research, v.36, p.3311-3324, 2000.

MONTANARI, R.; MARQUES JR., J.; PEREIRA, G.T.; SOUZA, Z.M. Forma da paisagem como critério para otimização amostral de latossolos sob cultivo de cana-de-açúcar. Pesquisa Agropecuária Brasileira, v.40, p.69-77, 2005.

PACHEPSKY, Y.A.; TIMLIN, D.J.; RAWLS, W.J. Soil water retention as related to topographic variables. Soil Science Society of America Journal, v.65, p.1787-1795, 2001.

PARK, S.J.; VLEK, P.L.G. Environmental correlation of threedimensional soil spatial variability: comparison of three adaptive techniques. Geoderma, v.109, p.117-140, 2002.
RAIJ, B. van; ANDRADE, J.C.; CANTARELLA, H.; QUAGGIO, J.A. (Ed.). Análise química para avaliação da fertilidade de solos tropicais. Campinas: Instituto Agronômico, 2001.

SADLER, E.J.; RUSSELL, G. Modeling crop yield for site-specific management. In: PIERCE, F.J.; SADLER, E.J. (Ed.). The state of site-specific management for agriculture. Madison: ASA; CSSA; SSSA, 1997. p.69-79.

SAS INSTITUTE. Statistical Analysis System for Windows: Computer program manual. Cary, 1995. 705p.

SILVEIRA, P.M.; ZIMMERMANN, F.J.P.; SILVA, S.C.; CUNHA, A.A. Amostragem e variabilidade especial de características químicas de um latossolo submetido a diferentes sistemas de preparo. Pesquisa Agropecuária Brasileira, v.35, p.2057-2064, 2000.

SOUZA, C.K.; MARQUES JR., J.; MARTINS FILHO, M.V.; PEREIRA, G.T. Influência do relevo na variação anisotrópica dos atributos químicos e granulométricos de um latossolo em Jaboticabal- SP. Engenharia Agrícola, v.3, p.486-495, 2003.

SOUZA, Z.M.; MARQUES JR., J.; PEREIRA, G.T.; MOREIRA, L.F. Variabilidade espacial do $\mathrm{pH}, \mathrm{Ca}, \mathrm{Mg}$ e V\% do solo em diferentes formas do relevo sob cultivo de cana-de-açúcar. Ciência Rural, v.34, p.1763-1771, 2004.

SURFER. Surfer 7.0. Contouring and 3D surface mapping for scientist's engineers. Version 7.0. User's Guide. New York: Golden Software, 1999. 619p.

TRANGMAR, B.B.; YOST, R.S.; WADE, M.K.; UEHARA, G. Applications of geostatistics to spatial studies of soil properties. Advances in Agronomy, v.38, p.45-94, 1985.

TROEH, F.R. Landform equations fitted to contour maps. American Journal of Science, v.263, p.616-627, 1965.

TSEGAYE, T.; HILL, R.L. Intensive tillage effects on spatial variability of soil test, plant growth, and nutrient uptake measurements. Soil Science, v.163, p.155-165, 1998.

VAIDYA, P.H.; PAL, D.K. Microtopography as a factor in the degradation of Vertisols in central India. Land Degradation \& Development, v.13, p.429-445, 2002.

VIEIRA, S.R.; HATFIELD, J.L.; NIELSEN, D.R.; BIGGAR, J.W. Geostatistical theory and application to variability of some agronomical properties. Hilgardia, v.51, p.1-75, 1983.

WARRICK, A.W.; NIELSEN, D.R. Spatial variability of soil physical properties in the field. In: HILLEL, D. (Ed.). Applications of soil physics. New York: Academic Press, 1980. p.319-344.

WOLLENHAUPT, N.C.; MULLA, D.J.; GRAWFORD, C.A.G. Soil sampling and interpolation techniques for mapping spatial variability of soil properties. The site-specific management for agricultural systems. Madison: ASA; CSSA; SSSA, 1997. p.19-53.

YOST, R.S.; UEHARA, G.; FOX, R.L. Geostatistical analysis of soil chemical properties of large land areas. I. Semivariograms. Soil Science Society of America Journal, v.46, p.1028-1032, 1982.

Received March 08,2005

Accepted March 02, 2006 